\title{
Shoreline algal wash as a factor in reed decline in Lake Constance-Untersee
}

\author{
Wolfgang Ostendorp \\ Limnologisches Institut Universität, Konstanz, Postfach 5560, W-7750 Konstanz, Germany \\ Received 9 August 1990; in revised form 29 September 1991; accepted 5 February 1992
}

Key words: Phragmites, Cladophora, Lake Constance, algal wash, reed decline

\begin{abstract}
This paper assesses the chemical and mechanical impact of algal wash (Cladophora, Spirogyra, Chara) upon the lakeside reed belt (Phragmites australis) using field mapping methods, bioassays with Scenedesmus acutus in batch culture, and field experiments. Heavy mats of filamentous algae are correlated with a reduction in number of the outermost reed stalks. The water pressed from decaying heaps of Cladophora and Spirogyra reduced the growth rate of Scenedesmus significantly, but mats from Chara did not. It is assumed that the toxic substance is an organic compound. In field experiments the detrimental effect could not be clearly evidenced. The reasons for this are discussed. It is concluded that mechanical impact is of major importance.
\end{abstract}

\section{Introduction}

A remarkable regress of lakeshore reedbelts (Phragmites australis (Cav.) Trin. ex Steud.) has been observed in Europe for more than twenty years (Ostendorp, 1989). In many cases the wash of filamentous algae on the shoreline has been regarded as a crucial factor in the reed decline (Utermöhl, 1982; Pries, 1984; Richter, 1983; Succow \& Reinhold, 1978; Binz, 1980; Dinka, 1986; Lake Constance: Schröder, 1979, 1987).

At the beginning of the century massive growth of filamentous algae was unknown in Lake Constance-Untersee; the littoral zone was covered with Chara contraria Kützing and Ch. aspera Willd., indicating the mesotrophic state of the lake (Baumann, 1911). In 1961-62 the first massive growth of Cladophora sp., Hydrodictyon reticulatum (L.) Lagerh., Oedogonium spp. and
Oscillatoria limosa Ag. was observed (Mattern, 1970). The algal mats near the shore were large enough to substantially hinder swimming and boating. The abundance of filamentous algae in the littoral zone reached its maximum in 19711974 (Schröder, 1986).

The 'die-back' of lakeside reeds in Lake Constance-Untersee began in the years between 1954 and 1962, intensified significantly in 1965 and 1966, and stopped in the beginning of the 1980s (Ostendorp, 1990). Because of the synchronism between algal abundance and reed decline it was suspected that the algal masses washed into the reeds could be detrimental to Phragmites, harming its vitality mechanically and/or chemically.

The present paper tries to shed light on this problem, presenting results from field measurements and laboratory experiments. 
Area of study, material and methods

The investigations were conducted at Lake Constance-Untersee. They are grouped into:

(a) mapping the flotsam of filamentous algae and submerged spermatophytes on the beach or in the first metres of the reedbelt;

(b) field measurements of chemical parameters in decaying algal mats and their vicinity,

(c) laboratory experiments, seeking toxic substances arising during the anaerobic decay of the algal mats;

(d) field experiments with natural reed stands to investigate the impact of algal deposits on the reed growth under controlled conditions.

\section{Flotsam mapping}

In late autumn of 1981,1982 and 1983 the wash was mapped along the shore, recording its distribution, quantity and taxonomic composition. The shoreline studied was $33.8 \mathrm{~km}$ long; it was subdivided into sections of a length of $100 \mathrm{~m}$ each. The quantity of wash in each section was estimated by means of a scale in six degrees, ranging from $G=0$ (no wash) to $G=5$ (heaps up to $40 \mathrm{~cm}$ in height and 10 to $25 \mathrm{~m}$ in lateral extension). The $G$ data were tested as to whether shore sections existed, which had been affected in the same way in all years (Goodman, 1979): the data sets of two years ( ${ }^{*}$ and ${ }^{* *}$ ) give a $6 \times 6$ cross classification table with the cells $\mathrm{m}_{\mathbf{i k}}$ $\left(\mathrm{i}=\mathrm{i}\left\{\mathrm{G}^{*}=0 \ldots 5\right\}\right.$, and $\left.\mathrm{k}=\mathrm{k}\left\{\mathrm{G}^{* *}=0 \ldots 5\right\}\right)$. The cell $\mathrm{m}_{24}$ for example contains the number of $100 \mathrm{~m}$-shore sections which were loaded to a degree of $\mathrm{G}^{*}=2$ in one year and to a degree of $\mathrm{G}^{* *}=4$ in the other year. The main diagonal of the matrix comprises the cells $m_{i k}$ with $i=k$, i.e. the cases for which the shore sections were loaded to the same extent in each year. The data matrix was transformed to a $\delta$-table with $\delta_{\mathrm{ik}}=\mathrm{G}_{\mathrm{i}}{ }^{*}-\mathrm{G}_{\mathrm{k}}{ }^{* *},-5 \leq \delta \leq+5$, weighted by the number of $100 \mathrm{~m}$-shore sections. For the main diagonal $\delta$ is zero. Now the data set was tested by the SAS 6.4 CATMOD procedure whether a $\mathrm{X}$ (columns)-effect, a Y(rows)-effect or a DIFF- (diagonal)-effect explains significantly the distribution of the observations over the cells. X,Y and DIFF were introduced into the model simultaneously. The results of the Maximum Likelihood Analysis in the CATMOD were used. The cells for $G^{*}, G^{* *}=3,4$ and 5 contained too little data, so they were pooled giving a $4 \times 4$ data matrix.

\section{Field measurements}

In selected positions the following parameters were measured within the algal mats:

* $\mathrm{pH}, \mathrm{pe}_{7}$ ('redox milieu', see Frevert, 1983), $\mathrm{pH}_{2} \mathrm{~S}$ ( $\equiv-\lg \mathrm{a}_{\mathrm{H} 2 \mathrm{~S}}$ ), measured simultaneously with an Ingold-combination probe (Ostendorp, 1982). The probe was stuck into the algal mats to a depth of 1 to $5 \mathrm{~cm}$, next to the adventitious roots of the reed stalks. $\mathrm{pS}_{\mathrm{t}}\left(\equiv-\lg \mathrm{a}_{\left(\mathrm{H} 2 \mathrm{~S}+\mathrm{Hs}^{2-}\right.}\right.$ $\left.+\mathrm{S}^{2-}\right)$ ) at a given $\mathrm{pH}$ was estimated according to Frevert \& Galster, 1978. $\mathrm{pH}_{2} \mathrm{~S}$-values greater than $10\left(\mathrm{H}_{2} \mathrm{~S}-\mathrm{S}\right.$ less than $\left.0.003 \mu \mathrm{g} \mathrm{l}^{-1}\right)$ indicate that the $\mathrm{S}^{2-}$ activity in the environment comes near to the solubility of the $\mathrm{Ag}_{2} \mathrm{~S}$-membrane of the probe $\left(\mathrm{pk}_{\mathrm{s}}=1.0 \cdot 10^{-49}, 18^{\circ} \mathrm{C}\right)$.

* Specific conductivity $\left(20^{\circ} \mathrm{C}\right)$ in $0.45 \mu$ membrane filtered water which had been squeezed from the mats.

\section{Laboratory experiments}

About $1 \mathrm{~kg}$ of fresh Chara, Spirogyra and Cladophora were sampled at the shore, mixed with lake water and put into 2.5 litre bottles. The clumps were allowed to decompose anaerobically for 6 weeks $\left(20^{\circ} \mathrm{C}\right.$, darkness). The suspension was then filtered stepwise through $2 \mathrm{~mm}$ to $0.2 \mu \mathrm{m}$-sieves and membrane filters, respectively; all steps were performed in a cold chamber $\left(4^{\circ} \mathrm{C}\right)$, the solution continuously exposed to the air to remove $\mathrm{Fe}^{2+}$ and $\mathrm{H}_{2} \mathrm{~S}-\mathrm{S}$. Hydrogen sulfide is known to be toxic to plant roots (Joshi et al., 1975; Mendelssohn et al., 1982), hence it was necessary to eliminate free sulfide from the test solutions by ventilation to demonstrate the existence of other toxic components. Toxic $\mathrm{Fe}^{2+}$ was 
oxidised and the ferric oxides were retained on the $0.2 \mu$-filter. After the ventilation step the $\mathrm{pe}_{7^{-}}$ value increased to $+2.6-+5.2$ (Table 4 ), indicating the (almost) complete absence of reduced electroactive compounds.

The filtered water from Chara, Spirogyra, and Cladophora mats was used as a substrate for nonaxenic batch cultures of Scenedesmus acutus Meien $\left(300 \mathrm{ml}\right.$ culture tubes, $23 \pm 1^{\circ} \mathrm{C}, 20,000$ lux normal light, 0.03 vol.- $\% \mathrm{CO}_{2}$, CHU-12 nutritive solution, according to Chu, 1942, modified by Müller, 1972). The solutions were inoculated with $10 \mathrm{ml}$ of an axenic, exponentially growing $S$. acutus suspension. The bioassays were run for eight days, comprising the phase of exponential growth between the second and the fifth day. The optical density at $720 \mathrm{~nm}, 1 \mathrm{~cm}$ cuvette length $\left(\mathrm{OD}_{720}\right)$ was taken as a measure for cell density. $0.45 \mu \mathrm{m}$-filtered solutions were used as blanks. Controls were made from pure CHU-12 solution, at normal concentration, and concentrated fivefold to estimate the significance of the increased salt and nutrient content in the test solutions. Triplicates were performed.

In a subsequent experiment the filtered water from decaying Cladophora clumps was fractionated into a volatile and a non-volatile fraction by lyophilisation, and the non-volatile fraction into lipophilic and hydrophilic substances by diethylether extraction. Following the ether distillation (rotation evaporator, $30^{\circ} \mathrm{C}$ ) the residue in the lipophilic fraction was suspended in bidistilled water. The fractions were added to concentrated nutritive solutions as in the previous experiment to give a substrate for a batch culture experiment with Scenedesmus.

\section{Field experiments}

In late autumn of 1981, 1982, and 1983 welldeveloped reed stands were selected for field experiments; the dead stalks were clipped off $1 \mathrm{~m}$ above the ground. A large plastic cylinder $(45 \mathrm{~cm}$ in diameter, $40 \mathrm{~cm}$ high) was put over the stand and pushed $10 \mathrm{~cm}$ deep into the sediment. The barrel was filled with c. $30 \mathrm{~kg}$ fresh matter of $\mathrm{Cla}$ - dophora or Chara wash from the shore nearby. A reference site (no mechanical damage, no natural algal wash) was established at a distance of 2 to $5 \mathrm{~m}$. The number of Phragmites stalks in each site was counted in autumn to ascertain detrimental effects of the algal wash.

\section{Results}

\section{Flotsam mapping}

The mapping of macrophyte deposits in the lakeside reedbelt of Lake Constance-Untersee showed a moderate contamination $(\mathrm{G}=2$ and 3$)$ for 22 to $41 \%$ and a very strong one ( $\mathrm{G}=4$ and 5) for 0 to $3 \%$ of the shoreline (Fig. 1, Table 1). The deposits consisted mainly of Cladophora (c. $50 \%$ on average) and to a lesser extent of sper-

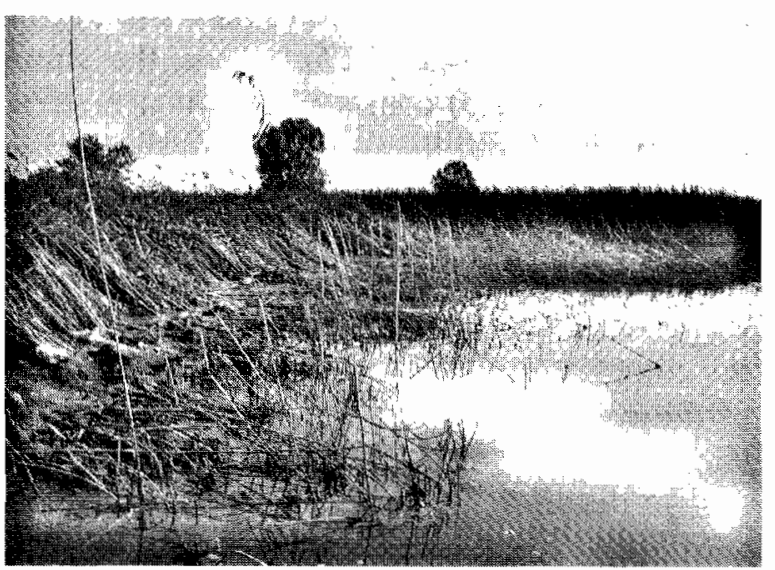

Fig. 1. Cladophora wash $(\mathrm{G}=5)$ in the reed front at Lake Constance-Untersee.

Table 1. Frequency distribution of $\mathrm{G}$ (quantity of algal wash, $\mathrm{G}=\mathrm{O}$ : no wash, $\mathrm{G}=5$ : very severe wash), percent of all shore sections investigated (1981: $n=177,1982: n=319,1983$ : $n=338$, each section $100 \mathrm{~m}$ long).

\begin{tabular}{lrrr} 
& 1981 & 1982 & 1983 \\
\hline $\mathrm{G}=0$ & $26.0 \%$ & $59.6 \%$ & $34.9 \%$ \\
$\mathrm{G}=1$ & $33.3 \%$ & $16.3 \%$ & $24.3 \%$ \\
$\mathrm{G}=2$ & $32.2 \%$ & $16.6 \%$ & $26.6 \%$ \\
$\mathrm{G}=3$ & $8.5 \%$ & $4.7 \%$ & $11.5 \%$ \\
$\mathrm{G}=4$ & $0.0 \%$ & $2.2 \%$ & $2.1 \%$ \\
$\mathrm{G}=5$ & $0.0 \%$ & $0.6 \%$ & $0.6 \%$ \\
\hline
\end{tabular}


Table 2. Share of each taxon in the washes (weighted, all shore sections pooled).

\begin{tabular}{lrrr}
\hline Taxon & 1981 & 1982 & \multicolumn{1}{c}{1983} \\
\hline Enteromorpha & $0.0 \%$ & $0.0 \%$ & $18.0 \%$ \\
Hydrodictyon & $6.3 \%$ & $0.0 \%$ & $0.0 \%$ \\
Cladophora & $73.4 \%$ & $32.0 \%$ & $50.1 \%$ \\
Spirogyra & $0.0 \%$ & $4.1 \%$ & $4.8 \%$ \\
Chara & $3.7 \%$ & $30.3 \%$ & $14.4 \%$ \\
Spermatophyta & $13.8 \%$ & $33.6 \%$ & $12.7 \%$ \\
\hline
\end{tabular}

matophytes like Elodea canadensis and Potamogeton spp., and of Chara spp. (Table 2). In 1983 Enteromorphaflexuosa was found for the first time in Lake Constance-Untersee (det. R. Kümmerlin, Langenargen); remarkably it made up not less than $18 \%$ of all deposits in its first season. The taxonomic composition of the flotsam varied greatly according to the magnitude of the wash: the slight and moderate washes ( $\mathrm{G}=1$ to 3 ) consisted in most cases of Cladophora, the strong ones ( $\mathrm{G}=4$ and 5) consisted of Chara material (Fig. 2).

The yearly intensities of the wash were tested for conformity, using the DIFF effect in the SAS CATMOD procedure as described above. The DIFF effect was found to be significant for the comparisons $1981 / 1983\left(\mathrm{chi}^{2}=14.2\right.$, degrees of freedom $\mathrm{df}=5$, prob $\left(\mathbf{H}_{0}=\right.$ independency $)=$ $0.015)$ and $1982 / 1983\left(\mathrm{chi}^{2}=16.8, \mathrm{df}=5\right.$, prob $=$

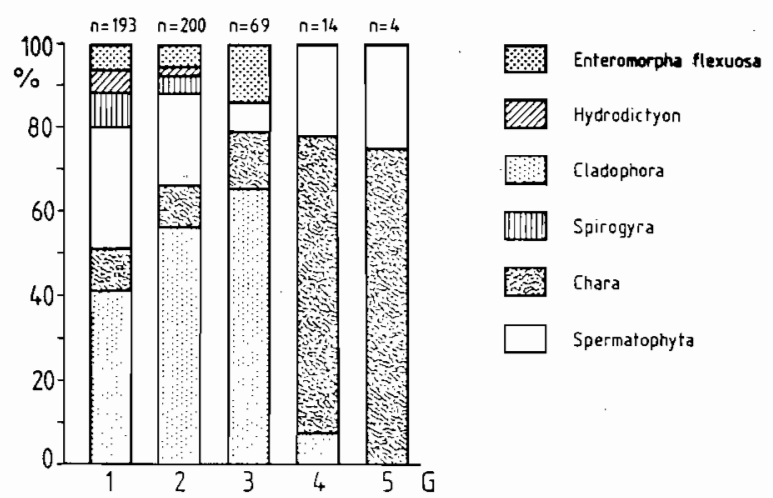

Fig. 2. Taxonomic composition of macrophyte washes which damage the reed front by the degrees $G=1$ (slightly) to $G=5$ (heavily) ( $\mathrm{n}$ - number of shore sections affected; pooled observations from 1981, 1982 and 1983).
$0.005)$, but not for $1981 / 1982\left(\mathrm{chi}^{2}=7.5, \mathrm{df}=4\right.$, prob $=0.112$ ). The $\mathrm{X}$ - and $\mathrm{Y}$-effects were significant (prob $<0.05$ ) for the combinations 1981/ 1983 and $1981 / 1982$ but not for 1982/1983 (Xeffect: prob $=0.330$ ). This means that in two of three cases the situation for $\mathrm{G}^{*}=\mathrm{G}^{* *}$ is more abundant in the field than would be expected under independency. Hence, it is assumed that, for a long period of time, a definite shore section will be affected in the same way; some sections will be contaminated less, some will suffer a more serious algal wash, on average.

\section{Chemical conditions inside the algal mats}

Table 3 shows the results of the in situ measurements in drifting algal clumps and in algal mats which were washed ashore, in comparison with reference data from the overlaying water and from the freely exchangeable littoral water.

The littoral water shows values that can frequently be met in the pelagic water of Lake Constance-Untersee. No traces of $\mathrm{H}_{2} \mathrm{~S}-\mathrm{S}$ could be detected $\left(\mathrm{pS}_{\mathrm{t}}>10\right)$. Inside the drifting clumps of living algae the chemical conditions were similar (no significantly different $\mathrm{pH}, \mathrm{pe}_{7}, \mathrm{pS}_{\mathrm{t}}$ and conductivity means at the $5 \%$-level).

When the Cladophora clumps were washed ashore and compacted, chemical conditions changed drastically. Compared with the free floating algae $\mathrm{pH}$ and $\mathrm{pe}_{7}$ were lowered significantly $(\alpha<0.05$ and $\alpha<0.01$, U-test), indicating anoxic decomposition processes, and the conductivity was higher $(\alpha<0.05$, U-test). A low accumulation of free $\mathrm{H}_{2} \mathrm{~S}-\mathrm{S}$ could be detected in only two sites ( $\mathrm{pS}_{\mathrm{t}}$ up to a maximum of $0.2 \mathrm{mg} \mathrm{S}^{-1}$ ). Similar conditions arose in rotting mats of Chara and Spirogyra. Spirogyra coats of only 0.5 to $1 \mathrm{~cm}$ thickness were sufficient to give rise to strongly reducing conditions.

The supernant water is affected by decaying Cladophora mats, exhibiting lower $\mathrm{pH}$-values $\left(\alpha<0.05\right.$, U-test) and lower $\mathrm{pe}_{7}$-values $(\alpha<0.10$, U-test) compared with the supernant water near freely floating algae. The specific conductivity does not differ significantly. 
Table 3. Chemical conditions within algal mats, in the supernant water of pools enclosed by algal dams, and in the free exchangeable littoral water (means and standard deviations); $\mathrm{pS}_{\mathrm{t}}>10$ : $\mathrm{S}^{2-}$ activity below the detection limit of the method; specific conductivity: $\mu \mathrm{S} \mathrm{cm}^{-1}, 20^{\circ} \mathrm{C}$; n.d.: not determined.

\begin{tabular}{|c|c|c|c|c|c|c|c|c|c|c|c|c|}
\hline & \multicolumn{4}{|c|}{ Inner parts of the algal mats } & \multicolumn{4}{|c|}{ Supernant water } & \multicolumn{4}{|c|}{ Free exchangeable littoral water } \\
\hline & $\mathrm{pH}$ & $\mathrm{pe}_{7}$ & $\mathrm{pS}_{\mathrm{t}}$ & Cond & $\mathrm{pH}$ & $\mathrm{pe}_{7}$ & $\mathrm{pS}_{\mathrm{t}}$ & Cond & $\mathrm{pH}$ & $\mathrm{pe}_{7}$ & $\mathrm{pS}_{\mathrm{t}}$ & Cond \\
\hline $\begin{array}{l}\text { Cladophora, } \\
\text { freely floating }\end{array}$ & $\begin{array}{c}8.4 \\
\pm 1.3 \\
(n=3)\end{array}$ & $\begin{array}{r}5.1 \\
\pm 0.5 \\
(n=3)\end{array}$ & $\begin{array}{l}>10 \\
(n=3)\end{array}$ & $\begin{array}{c}184 \\
\pm 13 \\
(n=3)\end{array}$ & 9.3 & 5.7 & $>10$ & 390 & $\begin{array}{c}8.9 \\
\pm 0.1 \\
(n=3)\end{array}$ & $\begin{array}{r}4.5 \\
+1.8 \\
(n=3)\end{array}$ & $\begin{array}{l}>10 \\
(n=3)\end{array}$ & 197 \\
\hline $\begin{array}{l}\text { Cladophora, } \\
\text { decaying mats }\end{array}$ & $\begin{array}{c}7.0 \\
\pm 0.7 \\
(n=9)\end{array}$ & $\begin{array}{l}-2.5 \\
\pm 3.1 \\
(n=9)\end{array}$ & $\begin{array}{l}>10^{\#} \\
(n=9)\end{array}$ & $\begin{array}{c}413 \\
\pm 47 \\
(n=3)\end{array}$ & $\begin{array}{c}7.6 \\
\pm 0.3 \\
(n=3)\end{array}$ & $\begin{array}{l}-0.1 \\
\pm 1.5 \\
(n=3)\end{array}$ & $\begin{array}{l}>10 \\
(n=3)\end{array}$ & $\begin{array}{r}435 \\
\pm 113 \\
(n=3)\end{array}$ & $\begin{array}{c}8.5 \\
\pm 0.9 \\
(n=7)\end{array}$ & $\begin{array}{c}3.2 \\
\pm 1.3 \\
(n=7)\end{array}$ & $\begin{array}{l}>10 \\
(n=7)\end{array}$ & $\begin{array}{c}252 \\
\pm 18 \\
(n=3)\end{array}$ \\
\hline $\begin{array}{l}\text { Chara, } \\
\text { decaying mats }\end{array}$ & 6.2 & -4.8 & 5.7 & 533 & \multicolumn{4}{|c|}{ n.d.* } & 8.3 & 2.3 & $>10$ & 270 \\
\hline $\begin{array}{l}\text { Spirogyra, } \\
\text { decaying mats }\end{array}$ & 7.0 & -3.0 & $>10$ & 195 & \multicolumn{4}{|c|}{ n.d.* } & \multicolumn{4}{|c|}{ n.d. } \\
\hline
\end{tabular}

\# 8 values $>10,1$ measurement yielded 5.3 .

* No supernant water at this site.

\section{Laboratory experiments}

During the period of decay the chemical properties in the vessel were repeatedly measured (Table 4). Similar to the conditions in the field the $\mathrm{pe}_{7}$-value dropped strongly, and the $\mathrm{pH}$-value decreased slightly. The $\mathrm{H}_{2} \mathrm{~S}-\mathrm{S}$ concentration increased but did not exceed $5 \mathrm{mg} \mathrm{S} 1^{-1}\left(\mathrm{pS}_{\mathrm{t}}=3.8\right)$. The conductivity was higher than in algal mats washed ashore.

Table 4. Chemical conditions in anaerobically decaying algal clumps (laboratory decay experiments): specific conductivity: $\mathrm{mS} \mathrm{cm}{ }^{-1}, 20^{\circ} \mathrm{C}$.

\begin{tabular}{|c|c|c|c|c|}
\hline & & Cladophora & Chara & Spirogyra \\
\hline \multirow[t]{3}{*}{ After 3 weeks } & $\mathrm{pH}$ & 5.8 & 6.5 & 5.4 \\
\hline & $\mathrm{pe}_{7}$ & -5.2 & -5.5 & -4.7 \\
\hline & $\mathrm{pS}_{\mathrm{t}}$ & 4.6 & 3.8 & 5.0 \\
\hline \multirow[t]{2}{*}{ After 6 weeks } & $\mathrm{pH}$ & 5.9 & 6.6 & 5.1 \\
\hline & $\mathrm{pe}_{7}$ & -5.2 & -4.7 & -4.2 \\
\hline , & $\mathrm{pS}_{\mathrm{t}}$ & 4.0 & 4.3 & 5.8 \\
\hline \multirow{4}{*}{$\begin{array}{l}\text { Immediately before } \\
\text { the algal assays } \\
\text { were run }\end{array}$} & $\mathrm{pH}$ & 7.1 & 7.9 & 5.7 \\
\hline & $\mathrm{pe}_{7}$ & +5.2 & +5.0 & +2.6 \\
\hline & $\mathrm{pS}_{\mathrm{t}}$ & $>10$ & $>10$ & $>10$ \\
\hline & Cond & 3.90 & 2.86 & 2.93 \\
\hline
\end{tabular}

The growth of Scenedesmus acutus in batch culture varied strongly according to the treatment (Table 6). Water pressed from Cladophora- and Spirogyra mats drastically reduced the growth rate. A deficiency of any micronutrient may be excluded because CHU 12 nutrient solution was always added. Hence, it is concluded that the pressed water contained an inhibitor. Evidently, neither $\mathrm{H}_{2} \mathrm{~S}-\mathrm{S}$ nor $\mathrm{Fe}^{2+}$ could be the inhibitor. The slight increase of the $\mathrm{OD}_{720}$ in the Cladophora and Spirogyra assays was due to bacterial infection.

In the second set of experiments the water pressed from Cladophora was separated into four fractions. Each fraction was used as a substrate for a Scenedesmus batch run. As in the experiments discussed above $\mathrm{pe}_{7}, \mathrm{pS}_{1}, \mathrm{pH}$ and specific conductivity were monitored during the decay and after all preparation steps immediately before the run was executed (Table 5). The decomposition conditions were similar to those in the previous experiments: strongly reducing conditions with a moderately high release of free $\mathrm{H}_{2} \mathrm{~S}-\mathrm{S}$ and a high release of other ions. After filtering the $\mathrm{pe}_{7}, \mathrm{pS}_{\mathrm{t}}$ and $\mathrm{pH}$ changed to normal values often found in the surface water of Lake ConstanceUntersee. 
Table 5. Chemical conditions during the anaerobic decay of Cladophora clumps (laboratory decay experiments) and in the fractions, immediately before the bioassays were run; specific conductivity: $\mathrm{mS} \mathrm{cm}^{-1}, 20^{\circ} \mathrm{C}$.

\begin{tabular}{lccccc}
\hline & $\begin{array}{l}\text { Decaying } \\
\text { algal clumps } \\
\text { before prep. }\end{array}$ & $\begin{array}{l}\text { Original } \\
\text { solution }\end{array}$ & $\begin{array}{c}\text { Hydrophilic } \\
\text { fraction } \\
\text { immediately before the algal assays were run }\end{array}$ & $\begin{array}{c}\text { Lipophilic } \\
\text { fraction }\end{array}$ & $\begin{array}{c}\text { Volatile } \\
\text { fraction }\end{array}$ \\
\hline $\mathrm{pH}$ & 6.9 & 7.9 & 9.2 & 6.6 & 7.0 \\
$\mathrm{pe}_{7}$ & -4.5 & +4.2 & +4.6 & +3.0 & +5.8 \\
$\mathrm{pS}_{\mathrm{t}}$ & 3.3 & $>10$ & $>10$ & $>10$ & $>10$ \\
Cond & 4.01 & 3.76 & 2.34 & 0.05 & 0.60 \\
\hline
\end{tabular}

Table 6. Growth rate of Scenedesmus bioassays during the exponential growth phase ( $\mathrm{OD}_{720} \mathrm{~d}^{-1}$, means and standard deviations). (a)-(b): controls, (c)-(f): pressed water from decaying algal mats, (g)-(i): pressed water from decaying Cladophora clumps after fractionation; statistical evaluation: unpaired t-test with estimated degrees of freedom for unequal variances, levels of significance: n.s. - not significant, ${ }^{*}-0.05,{ }^{* *}-0.01,{ }^{* * *}-0.001$.

\begin{tabular}{|c|c|c|c|c|c|c|c|c|c|c|}
\hline Test & Growth rate & (a) & (b) & (c) & (d) & (e) & (f) & $(\mathrm{g})$ & (h) & (i) \\
\hline (a) $\mathrm{CHU}$ 12, normal concentr. & $0.607 \pm 0.104$ & _- & * & $* *$ & ** & n.s. & ** & n.s. & * & n.s. \\
\hline (b) CHU $12,5 \times$ concentrated & $0.906 \pm 0.079$ & & - & $* *$ & $* *$ & n.s. & ** & n.s. & $* * *$ & $* *$ \\
\hline (c) + Cladophora pressed water & $0.049 \pm 0.024$ & & & - & n.s. & $* * *$ & $* *$ & $* *$ & $* *$ & * \\
\hline (d) + Spirogyra pressed water & $0.025 \pm 0.033$ & & & & - & $* * *$ & * & ** & $* *$ & * \\
\hline (e) + Chara pressed water & $0.848 \pm 0.009$ & & & & & - & $* * *$ & n.s. & ** & $*$ \\
\hline (f) + Cladophora, original sol. & $-0.052 \pm 0.020$ & & & & & & - & ** & $* *$ & * \\
\hline (g) + Cladophora, hydrophilic fr. & $0.738 \pm 0.101$ & & & & & & & - & ** & * \\
\hline (h) + Cladophora, lipophilic fr. & $0.324 \pm 0.057$ & & & & & & & & - & n.s. \\
\hline (i) + Cladophora, volatile fr. & $0.379 \pm 0.114$ & & & & & & & & & - \\
\hline
\end{tabular}

However, the separation into four fractions led to different chemical starting conditions for the algal growth: the largest quantity of ions was found in the hydrophilic fraction, whereas in the lipophilic fraction the ion concentration was lower than in the lake water. Significant quantities of free $\mathrm{H}_{2} \mathrm{~S}-\mathrm{S}$ could not be found in any fraction; hence, $\mathrm{H}_{2} \mathrm{~S}-\mathrm{S}$ could be excluded as an inhibitor.

The batch run with Scenedesmus showed a strong inhibition for the original solution (the growth rate turned negative with time perhaps due to dissolution of carbonate precipitates and/or oxidation of suspended $\mathrm{S}^{0}$ to $\mathrm{SO}_{4}^{2-}$ ), and a clear inhibition for the lipophilic and the volatile fraction (Table 6). No significant difference could be observed between the controls and the hydrophilic fraction.

\section{Field experiments}

In late autumn the test barrels were filled with Cladophora- and Chara clumps as described above. No flush of the algal mats by wave action was observed during the flooding period in summer. No algae mats were attached at the Phragmites stalks. Hence, any mechanical damage by filamentous algae + wave action could be excluded as a significant factor. The data are shown in Table 7. In the Cladophora test vessels the mean stalk number decreased as well as in the controls (Table 7a). No significant difference could be found between the mean stalk number differences of the tests and the controls (Table 7b). At the Chara sites, tests and controls exhibited an increased stalk density. However, no significance was detected between the increase in the tests and 
Table 7. Impact of Cladophora and Chara mats on Phragmites stands - results of field experiments.

7a: Number of stalks in a test vessel at the beginning of the experiment and at the end of the following growth season, means and standard deviations.

7b: Difference in stalk number between 'start' and 'end' (mean differences and standard deviations;

statistical evaluation: paired t-test for pairs with the same sample size, unpaired t-test for pairs with unequal sample sizes, levels of significance: see Table 6 .

(a)

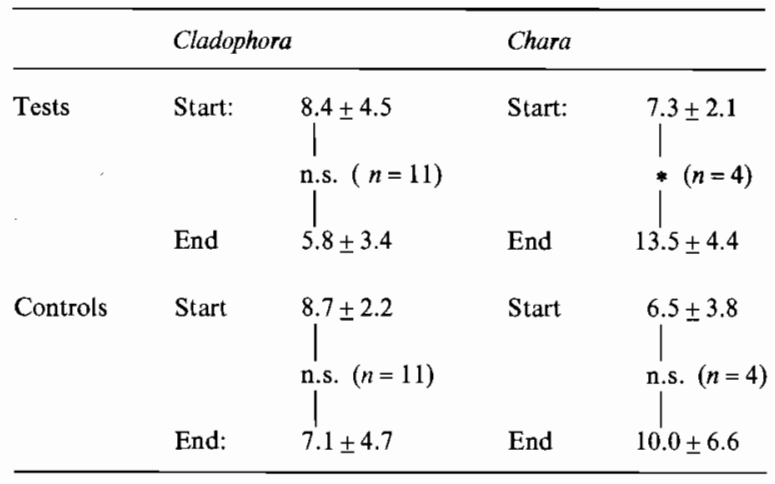

(b)

\begin{tabular}{lll}
\hline & Cladophora & Chara \\
\hline Tests & $\Delta=-2.6 \pm 4.3(n=11)-* *-\Delta=+6.3 \pm 3.7(n=4)$ \\
Controls & $\Delta=-1.6 \pm 4.8(n=11)-$ n.s. $-\Delta=+3.5 \pm 3.0(n=4)$
\end{tabular}

the increase in the controls. Comparing the two sites, it can be stated that the controls do not differ significantly, but the tests do (Table 7b).

\section{Discussion}

The mapping of macrophyte washes showed that about $35 \%(=11 \mathrm{~km})$ of the reed-covered shoreline is frequently affected (Table 1). The stalks are bent down by the algal masses, and the leaves are submerged. Flooded Phragmites leaves exhibit a reduced photosynthetic activity (Rodewald-Rudescu, 1974: 81), diminishing perhaps the intensity of carbohydrate and oxygen transport to the roots. In many cases the wash was significant enough to break down the stalks, thereby dam- aging the aerenchyma channels which became filled with water. As a consequence, the oxygen supply of the underground organs is interrupted (Armstrong \& Armstrong, 1988), and, after a short period of anoxic metabolism, the rhizome will die down due to deficiency of carbohydrate reserves (Haldemann \& Brändle, 1986; Brändle, 1990). It is assumed that the death of a part of the rhizome system cannot be compensated for until the next season by newly growing rhizomes. Hirscher, 1987 found a connection between the degree of mechanical damage - mostly by drifting plant matter - and the differences in stalk number between subsequent years (Fig. 3): the difference is negative for strongly affected stands, and evidently these stands will die back if the damaging goes on for some years.

Whether a flotsam is formed or not, at which site, and to what size, depends upon numerous factors (Hagenmeyer \& Krumscheid-Plankert, 1990). One of them is the type of sublittoral vegetation as was demonstrated here: we find $\mathrm{Cla}$ dophora as a main constituent of flotsams of mod-

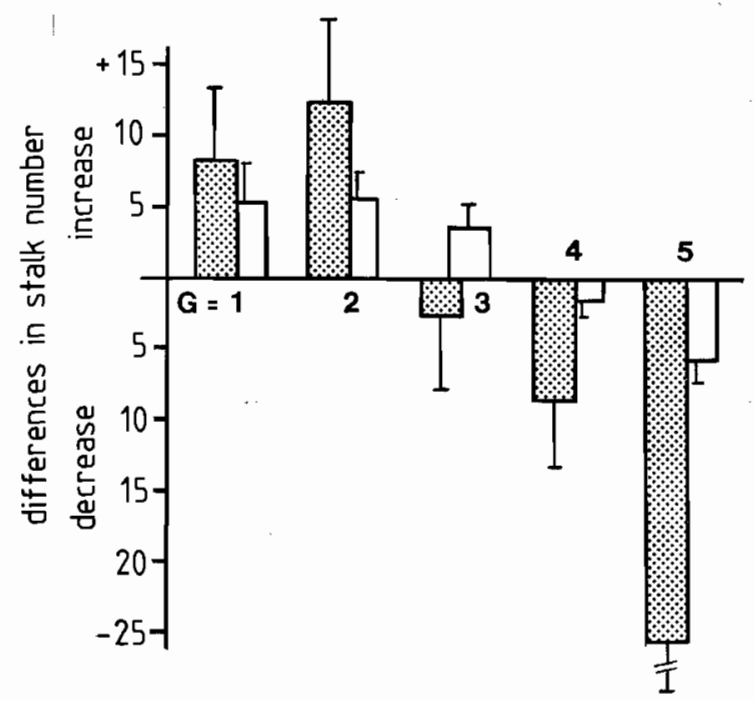

Fig. 3. Development of the lakeward reed front depending on the degree of mechanical damage to the reeds, Lake Constance-Obersee (decrease/increase: change of stalk number per $5 \mathrm{~m}$ shore section $1985-1986, \mathrm{G}=1$ - slightly, $\mathrm{G}=5$ - heavily damaged, $n=5$ to 33 shore sections, dolled bars total number of stalks, blank bars - number of primary (= panicle bearing) shoots; means and standard errors of the mean), data from Hirscher, 1987. 
erate thickness, and Chara of large ones (Fig. 2). Freely floating mats of Cladophora, Hydrodictyon and others are transported by even a gentle breeze, whereas storms are needed to tear out attached taxa like Chara, Najas, Elodea and Potamogeton.

If filamentous algae drift as loose clumps photosynthesis is maintained and chemically reducing conditions do not occur at least during day time. However, if algal clumps are thrown onto the beach by wave action, then they are compacted and water exchange and light penetration are reduced. Respiration processes and anaerobic decay lead to an oxygen depletion (Thomas, 1960) and to strongly reducing conditions (Table 3). Spirogyra coats of not more than 0.5 to $1 \mathrm{~cm}$ thickness were sufficient to give rise to an anaerobic decay.

Under these conditions $\mathrm{Fe}^{2+}$ and $\mathrm{H}_{2} \mathrm{~S}-\mathrm{S}$ can be released $\left(\mathrm{pe}_{7}<+4\right.$, and $\mathrm{pe}_{7}<-3$, respectively, see Frevert, 1983) to give toxic concentrations for the adventitious roots of Phragmites (Joshi et al., 1975; Mendelssohn et al., 1982). In an alkaline milieu both ions can combine to $\mathrm{FeS}$, hydrotroilite, thereby lowering their toxic potential. In the littoral sediments of Lake Constance-Untersee total $\mathrm{Fe}$ is present in greater amounts than total S(II) (0.5-1 vs. 0.00030.002 moles $\mathrm{kg}^{-1}$ dry matter); presumably a great proportion of the released $\mathrm{H}_{2} \mathrm{~S}-\mathrm{S}$ is precipitated as FeS (Müller, 1967). This explains that only small amounts could be measured in decaying algal mats in the field.

Algal mats often form small dams in front of the reedbeds, enclosing pools of stagnant water which have low exchange with the littoral water. The chemical properties of these water bodies are largely influenced by the decaying algae (Table 3 ).

The decay of algal wash was simulated in laboratory experiments, and a batch culture of the planktonic alga Scenedesmus acutus was used as a simple test system for toxic substances (Healey, 1979). The free $\mathrm{H}_{2} \mathrm{~S}-\mathrm{S}$ that accumulated due to a lack of Fe-rich muds was eliminated by oxidation and filtering. The growth rate of Scenedesmus was greatly reduced when the water pressed from $\mathrm{Cla}$ dophora and Spirogyra mats was added, but for
Chara mats no detrimental effect occurred. A lack of any micronutrient could be excluded as well as inhibiting effect of the increased salt content (Table 6). Hence, the experiments strongly suggest that a toxic substance was formed. It is concluded that the chemical conditions in the laboratory decay experiments were comparable to those in washes (Tables 4,5 ). If an inhibitor was to be formed in the bottle experiments due to anoxic microbial metabolism it should also be formed in the field. In a subsequent experiment the pressed water of Cladophora clumps were fractionated into hydrophilic, lipophilic, and volatile substances. Only the last two fractions inhibited Scenedesmus growth. This suggests that organic substances are the phytotoxins.

Allelopathic effects are well known among aquatic plants (Wium-Andersen, 1987), but only in few cases the chemical nature of the toxic substance(s) is elucidated (e.g. Wium-Andersen et al., 1982). As to the literature available there is no evidence for allelopathic substances in living Cladophora or Spirogyra algae. It seems therefore likely that the toxic substances do not develop until autolysis and/or microbially mediated decay starts. Jüttner et Schröder, 1982 could identify many volatile organic compounds in the sediments of declining reed beds of Lake ConstanceUntersee: some of them were thought to arise from algal metabolism or from the microbial lipid degradation of algal remains. However, the phytotoxic potential of these compounds is unclear.

The inhibitory properties of Cladophora and Chara wash upon Phragmites were tested in field experiments. Contrary to the laboratory bioassays no clearcut effect was observed: the reed plants in the test vessels reacted the same as those in the controls. Possibly the toxic substances formed did not reach the Phragmites roots:

- the field assays were established in late autumn when most of the overground stalks and adventive roots were dead,

- in winter when the water table of Lake Constance drops down below the level of the littoral floor, the sediment remains water saturated. Substances cannot penetrate into the 
sediment against the countercurrent of the groundwater, and the deeper lying roots remained uneffected.

It is concluded therefore, that - under field conditions - the chemical impact of algal wash is of minor importance at most sites. The formation of toxic substances in decaying Cladophora mats cannot explain all the reed decline in Lake Constance-Untersee. The mechanical damage, as experienced by Hirscher, 1987 and Hagenmeyer et Krumscheid-Plankert 1990, seems to be decisive for the recent development of the reed front. However, the problem needs further attention, and additional field and laboratory experiments should be performed, wherever reed decline occurs in context with algal wash.

\section{Acknowledgements}

I wish to thank F. Jüttner (ETH Zürich) for some suggestions concerning the preparation steps of the decay experiments, W. Nagl (Rechenzentrum Univ. Konstanz) for statistical helpings, and S. J. Turrell for linguistic comments.

\section{References}

Armstrong, J. \& W. Armstrong, 1988. Phragmites australis a preliminary study of soil-oxidizing sites and internal gas transport pathways. New Phytol. 108: 373-382.

Baumann, E., 1911. Die Vegetation des Untersees (Bodensee). Arch. Hydrobiol. Suppl. 1: 1-554.

Binz, H. R., 1980. Der Schilfrückgang - ein Ingenieurproblem? Jber. Verb. Schutz Landschaftsbild Zürichsee 53: 35-52.

Brändle, R., 1990. Überlebensstrategien der Rhizome von Sumpf- und Röhrichtpflanzen. In H. Sukopp \& M. Krauss (eds), Ǒkologie, Gefährdung und Schutz von Röhrichtpflanzen. Landschaftsentwicklung und Umweltforschung (Berlin) 71: 103-120.

Chu, S. P., 1942. The influence of mineral composition of the medium on the growth of planktonic algae. I. Methods and cultural media. J. Ecol. 30: 284-325.

Dinka, M., 1986. The effect of mineral nutrient enrichment of Lake Balaton on the Common Reed (Phragmites australis). Folia Geobot. Phytotax. 21: 65-84.

Frevert, T., 1983. Hydrochemisches Grundpraktikum. Birkhäuser, Basel, 215 pp.

Frevert, T. \& H. Galster, 1978. Schnelle und einfache
Methode zur In-Situ-Bestimmung von Schwefelwasserstoff in Gewässern und Sedimenten. Schw. Z. Hydrol. 40: 199208.

Goodman, L. A., 1979. Multiplicative models for the analysis of occupational mobility tables and other kinds of crossclassification tables. Am. J. Soc. 84: 804-819.

Hagenmeyer, Th. \& P. Krumscheid-Plankert, 1990. Zur Dynamik und Schädigung der Schilfgebiete im Bodenseekreis. Report of Limnologisches Institut d. Universität Konstanz, 109 pp.

Haldemann, Ch. \& R. Brändle, 1986. Jahreszeitliche Unterschiede im Reservestoffgehalt und von Gärungsprozessen in Rhizomen von Sumpf- und Röhrichtpflanzen aus dem Freiland. Flora 178: 307-313.

Healey, F. P., 1979. The use of growth rate for testing toxicant effects on algae. In E. Scherer (ed.), Toxicity tests for freshwater organisms. Can. Spec. Publ. Fish. aquat. Sci. 44: 57-70.

Hirscher, A., 1987. Dokumentation der Schilfbestandsentwicklung (Lipbach-Strandbad Friedrichshafen-Eriskircher Ried) Frühjahr-Herbst 1986. Report of the Landkreis Bodenseekreis, Friedrichshafen (FRG), 37 pp.

Jüttner, F. \& R. Schröder, 1982. Microbially derived volatile organic compounds in the recent sediment of the Phragmites australis bed of the Bodensee (Lake Constance). Arch. Hydrobiol. 94: 172-181.

Joshi, M. M., I. K. A. Ibrahim \& J. P. Hollis, 1975. Hydrogen sulfide: effects on the physiology of Rice plants and relation to straighthead disease. Phytopathology 65: 11651170 .

Mattern, H., 1970. Beobachtungen über die Algenflora im Uferbereich des Bodensees (Überlinger See und Gnadensee). Arch. Hydrobiol. Suppl. 37: 1-163.

Mendelssohn, I. A. \& K. L. McKee, 1982. Sublethal stresses controlling Spartina altemiflora productivity. In B. Gopal, R. E. Turner, R. G. Wetzel \& D. F. Whigham (eds), Wetlands, Ecology and Management. Proc. 1st Int. Wetland Conf. 1980, New Delhi: 223-242.

Müller, G., 1967. Beziehungen zwischen Wasserkörper, Bodensediment und Organismen im Bodensee. - Naturwissenschaften 54: 454-466.

Müller, H., 1972. Wachstum und Phosphat-Bedarf von Nitzschia actinastroides (Lemm.) v. Goor in statischer und homokontinuierlicher Kultur unter Phosphatlimitierung. Arch. Hydrobiol. Suppl. 38: 399-484.

Ostendorp, W., 1982. Konstanzer Methoden der Röhrichtforschung. Report of Limnologisches Institut d. Univ. Konstanz, 75 pp., Constance.

Ostendorp, W., 1989. 'Die-back' of reeds in Europe - a critical review of literature. Aquat. Bot. 35: 5-26.

Ostendorp, W., 1990. Die Ursachen des Röhrichtrückgangs am Bodensee-Untersee. Carolinea 48: 85-102.

Pries, E., 1984. Verlauf, Umfang und Ursachen des RöhrichtRückganges an uckermärkischen Seen und seine Auswirkungen auf Rohrsängerbestände. Naturschutzarbeit in Mecklenburg 27: 3-19, 72-82. 
Richter, W. M., 1983. Veränderung der Bestånde von Phragmites australis im Breiten Luzin bei Feldberg (Mecklenburg). Acta Hydrochim. Hydrobiol. 12: 601-607.

Rodewald-Rudescu, L., 1974. Das Schilfrohr. Die Binnengewässer 27: 1-302, Stuttgart.

Schröder, R., 1979. The decline of reed swamps in Lake Constance. Symp. Biol. Hung. 19: 43-48.

Schröder, R., 1986. Die Veränderung der Wasserpflanzengesellschaft im Untersee und im südlichen Überlinger See als Abbild der trophischen Entwicklung. Report of the 1nstitut für Seenforschung Langenargen, $11 \mathrm{pp}$.

Schröder, R., 1987. Schilfsterben am Bodensee-Untersee. Beobachtungen, Untersuchungen und Gegenmaßnahmen. Arch. Hydrobiol. Suppl. 76: 53-99.

Succow, M. \& A. Reinhold, 1978. Das Vegetationsgefúge eines jungpleistozänen Klarwassersees und seine Belastung
- eine Studie mit Hilfe von Farbluftbildern. Limnologica 11: $355-377$.

Thomas, E. A., 1960. Sauerstoffminima und Stoffkreisläufe im ufernahen Oberflächenwasser des Zürichsees (Cladophora- und Phragmites-Gürtel). Monatsbull. Schweiz. Ver. Gas- u. Wasserfachm. 40: 140-167.

Utermohl, H., 1982. Die Vernichtung von Phragmites durch Cladophora im Großen Plöner See. Arch. Hydrobiol. 95: 487-490.

Wium-Andersen, S., 1987. Allelopathy among aquatic plants. Arch. Hydrobiol. Beih. 27: 167-172.

Wium-Andersen, S., U. Anthoni, C. Christophersen \& G. Houen, 1982. Allelopathic effects on phytoplankton by substances isolated from aquatic macrophytes (Charales). Oikos 39: 187-190. 